\title{
Pengaruh Struktur Kepemilikan dan Ukuran Perusahaan Pada Praktik Perataan Laba
}

\author{
A.A. Sagung Nur Andiani ${ }^{1}$ \\ Ida Bagus Putra Astika ${ }^{2}$ \\ ${ }^{1,2}$ Fakultas Ekonomi dan Bisnis Universitas Udayana (Unud), Bali, Indonesia \\ e-mail: sagungandiani@gmail.com
}

\begin{abstract}
ABSTRAK
Pasar modal makin berkembang dari waktu ke waktu. Perusahaan menerbitkan saham untuk mendapat sejumlah modal dari investor. Laba merupakan salah satu indikator utama untuk mengukur kinerja dan pertanggung jawaban manajemen. Perhatian Investor cenderung hanya terpusat pada laba, manajemen menyadari bahwa informasi laba merupakan hal yang terpenting bagi suatu perusahaan, sehingga manajer terdorong untuk melakukan praktik perataan laba. Penelitian ini bertujuan untuk mendapatkan bukti empiris pengaruh struktur kepemilikan dan ukuran perusahaan pada praktik perataan laba pada perusahaan manufaktur yang terdaftar di Bursa Efek Indonesia. Jumlah sampel yang terpilih pada perusahaan manufaktur adalah sebanyak 25 perusahaan, dengan menggunakan metode purposive sampling. Penelitian ini diuji dengan Uji Logistik dan Hasil penelitian menunjukkan bahwa struktur kepemilikan manajerial dan ukuran perusahaan tidak berpengaruh pada praktik perataan laba sedangkan struktur kepemilikan institusional berpengaruh positif pada praktik perataan laba.
\end{abstract}

Kata Kunci: Praktik perataan laba, kepemilikan manajerial, ukuran perusahaan.

\begin{abstract}
The capital market is growing from time to time. The company issues shares to obtain capital from investors. Profit is one of the main indicators for measuring performance and management accountability. Attention Investors tend to only focus on profit, management realizes that earnings information is the most important thing for a company, so managers are encouraged to practice income smoothing. This study aims to obtain empirical evidence of the influence of ownership structure and firm size on income smoothing practices in manufacturing companies listed on the Indonesia Stock Exchange. The number of samples selected in manufacturing companies is as many as 25 companies, using the purposive sampling method. This research was tested by Logistic Test and the results showed that the structure of managerial ownership and firm size did not affect the income smoothing practice while the institutional ownership structure had a positive effect on income smoothing practices.
\end{abstract}

Keywords: Income smoothing practices, managerial ownership, firm size

\section{PENDAHULUAN}

Perkembangan pasar modal semakin pesat di Indonesia. Perusahaan menerbitkan saham untuk mendapat sejumlah modal dari investor. Investor membeli saham dengan tujuan mengharap keuntungan berupa deviden. Investor membutuhkan laporan keuangan Ketika akan melakukan investasi, pertama-tama investor harus 
A. A. Sagung Nur Andiani dan Ida Bagus Putra Astika. Pengaruh ...

memilih perusahaan yang kinerjanya baik sehingga diharapkan dapat menghasilkan keuntungan yang diinginkan. Akan tetapi, investor terkendala masalah keterbatasan informasi dikarenakan hanya pihak manajemen atau orang dalam yang mengetahui kinerja perusahaan.

Bursa Efek Indonesia sebagai pasar modal merupakan tempat bagi investor dalam melakukan kegiatan investasi dan mendapatkan invormasi yang relevan tentang perusahaan yang nantinya akan berpengaruh terhadap harga saham perusahaan tersebut (Dewi et al., 2018). Persaingan antar perusahaan untuk menarik minat para investor semakin hari semakin terlihat dari usaha manajemen untuk memperbaiki kinerja perusahaannya. Penilaian perusahaan sangat tergantung dari bagaimana pihak manajemen perusahaan mampu mengelola asset untuk dapat memperoleh laba tersebut.

Informasi laporan keuangan perusahaan merupakan salah satu pertimbangan pemegang saham dalam proses pengambilan keputusan di pasar modal. Laporan yang diterbitkan oleh perusahaan memberikan sumber informasi mengenai posisi keuangan perusahaan, kinerja serta perubahan posisi keuangan yang sangat berguna untuk pengambilan keputusan. Semua unsur yang terdapat dalam laporan keuangan tersebut mengandung informasi yang sangat penting bagi pemakai laporan keuangan (Michelson et al., 2011).

Laporan keuangan merupakan alat utama para manajer untuk menunjukkan efektivitas pencapaian tujuan dan untuk melaksanakan fungsi pertanggungjawaban dalam organisasi. Dalam Standar Akuntansi Keuangan (IAI, 2009:3) disebutkan bahwa "tujuan laporan keuangan adalah menyediakan 
informasi yang menyangkut posisi keuangan, kinerja serta perubahan posisi keuangan suatu perusahaan yang bermanfaat bagi sejumlah besar pemakai dalam pengambilan keputusan ekonomi. Laporan keuangan juga menunjukkan seberapa besar kinerja suatu manajemen dan menjadi sumber dalam mengevaluasi kinerja manajemen. Salah satu parameter penting dalam laporan keuangan yang digunakan untuk mengukur kinerja manajemen adalah laba, yang disajikan pada laporan laba rugi” (Zaitul \& Muslim, 2014).

Laba merupakan salah satu indikator utama untuk mengukur kinerja dan pertanggung jawaban manajemen. Informasi laba dapat dijadikan panduan dalam melakukan investasi yang membantu investor ataupun pihak lain dalam menilai earnings power (kemampuan menghasilkan laba) perusahaan di masa yang akan datang. Adanya kecenderungan memperhatikan laba ini disadari oleh manajemen, khususnya manajer yang kinerjanya diukur berdasarkan informasi laba tersebut, sehingga mendorong munculnya manajemen laba.

Fenomena manajemen laba seperti dua sisi mata uang. Pada satu sisi, manajemen laba adalah produk yang legitimate, disisi lain manajemen laba dianggap sebagai produk dari suatu tindakan yang immoral dan unethical. Manajemen laba oleh sebagian kalangan dianggap sebagai professional judgement atas laporan keuangan, tetapi dapat menyesatkan pihak stakeholder dalam melakukan interpretasi terhadap performa ekonomi suatu perusahaan (Giovani, 2017). Tindakan ini dilakukan karena standar akuntansi memberikan kebebasan untuk memilih metoda yang akan digunakan dan sikap oportunistik manajer. 
A. A. Sagung Nur Andiani dan Ida Bagus Putra Astika. Pengaruh ...

Manajemen laba terjadi ketika para eksekutif mengatur pelaporan keuangan dengan mengelola transaksi sehingga mengubah laporan keuangan. Terdapat berbagai persepsi mengenai manajemen laba yang dilakukan oleh perusahaan, salah satunya akademisi berpendapat bahwa manajemen laba itu tidak buruk dengan mengansumsikan bahwa laporan keuangan telah mengungkapkan seluruh manajemen laba yang dilakukan, atau dengan kata lain manajemen laba yang baik adalah manajemen laba yang masih dalam batasan aturan standar akuntansi keuangan (SAK). Sedangkan manajemen laba yang buruk yaitu menyajikan kinerja keuangan yang menyesatkan dengan tidak mengungkapkan seluruhnya maupun sebagian mengenai dampaknya terhadap kinerja keuangan (Puspitasari \& Putra, 2018).

Manajemen laba dikelompokkan menjadi empat bagian yaitu taking a bath, income minimization (minimalisasi laba), income maximization (maksimalisasi laba) dan income smoothing (perataan laba). Tindakan manipulasi yang dilakukan tidak semata hanya untuk kepentingan perseorangan, para manajer termotivasi melakukan perataan penghasilan disebabkan tuntutan yang dilakukan oleh para pemilik perusahaan tersebut. Kasus manajemen laba yang terjadi menyebabkan menurunnya kepercayaan investor terhadap perusahaan, salah satu manajemen laba yang digunakan memanipulasi laporan keuangan adalah income smoothing (perataan laba) (Sidartha, 2017).

Perataan laba merupakan salah satu dari tindakan manajemen laba yang dilakukan pihak manajer untuk mengurangi fluktuasi laba yang dilaporkan sehingga laba dapat terlihat stabil dari periode ke periode setelahnya. Laba yang 
terlihat stabil ini akan menarik minat investor untuk menanamkan modalnya di perusahaan, karena laba yang stabil mengindikasikan bahwa kondisi perusahaan terlihat baik. Dalam pertaan laba, manajer berusaha untuk membuat pergerakan atau naik turunnya laba terlihat smooth dalam batas - batas yang diijinkan oleh standar akuntansi yang berlaku (Gayatri dan Wirakusuma, 2013). Hal tersebut berarti manajer dapat mengganti metode akuntansi yang digunakan dengan metode lain yang tersedia dalam standar akuntansi dengan asumsi bahwa metode sebelumnya sudah tidak relevan lagi untuk digunakan. Walaupun demikian tindakan perataan laba tetap merugikan pemegang saham karena informasi yang dihasilkan berbeda dengan kondisi yang sebenarnya sehingga dapat membuat pemegang saham menjadi salah dalam mengambil keputusan tersebut.

Di Indonesia terdapat banyaknya fenomena Perataan Laba yang terjadi pada perusahaan besar. Diantaranya adalah pada Kasus PT Inovisi Infracom (INVS) pada tahun 2015. Dalam kasus ini Bursa Efek Indonesia (BEI) menemukan indikasi salah saji dalam laporan keuangan INVS periode September 2014. Dalam keterbukaan informasi INVS bertanggal 25 Februari 2015, ada delapan item dalam laporan keuangan INVS yang harus diperbaiki. BEI meminta INVS untuk merevisi nilai aset tetap, laba bersih per saham, laporan segmen usaha, kategori instrumen keuangan, dan jumlah kewajiban dalam informasi segmen usaha. Selain itu, BEI juga menyatakan manajemen INVS salah saji item pembayaran kas kepada karyawan dan penerimaan (pembayaran) bersih utang pihak berelasi dalam laporan arus kas. Pada periode semester pertama 2014 pembayaran gaji pada karyawan Rp1,9 triliun. Namun, pada kuartal ketiga 2014 
A. A. Sagung Nur Andiani dan Ida Bagus Putra Astika. Pengaruh ...

angka pembayaran gaji pada karyawan turun menjadi Rp59 miliar. Sebelumnya, manajemen INVS telah merevisi laporan keuangannya untuk periode Januari hingga September 2014. Dalam revisinya tersebut, beberapa nilai pada laporan keuangan mengalami perubahan nilai, salah satu contohnya adalah penurunan nilai aset tetap menjadi Rp1,16 triliun setelah revisi dari sebelumnya diakui sebesar Rp1,45 triliun. Inovisi juga mengakui laba bersih per saham berdasarkan laba periode berjalan. Praktik ini menjadikan laba bersih per saham INVS tampak lebih besar. Padahal, seharusnya perseroan menggunakan laba periode berjalan yang diatribusikan kepada pemilik entitas induk.

Selain itu terdapat juga fenomena yang melakukan perataan laba pada PT Saratoga Investama Sedaya Tbk. (SRTG) Pada semester I 2016, portofolio investasi PT Saratoga Investama Sedaya Tbk. (SRTG) tumbuh sebesar 26\% dari Rp 13,6 triliun pada 31 Desember 2015 menjadi Rp 17,1 triliun pada 30 Juni 2016. Pertumbuhan portofolio itu terutama diperoleh dari peningkatan nilai pasar dari investasi Perseroan di sektor sumber daya alam serta didukung oleh kinerja kuat dan berkelanjutan perusahaan investasi di sektor infrastruktur dan konsumer. Mulai semester I tahun 2016, Saratoga telah menerapkan "Pernyataan Standar Akuntansi Keuangan (PSAK) 65: Pengecualian Konsolidasi” dalam pelaporan kinerja keuangan Perseroan. PSAK 65 baru tersebut memungkinkan Saratoga untuk menerapkan nilai wajar atas aset-aset investasinya. Karena perubahan ini diterapkan secara prospektif (berlaku ke depan), laporan kinerja keuangan perseroan di 2016 tidak dapat dibandingkan dengan laporan keuangan konsolidasi tahun 2015. 
Pada semester pertama tahun 2016, PT Triwahana Universal (TWU) menghentikan produksinya karena terhentinya pengadaan pasokan minyak mentah sehubungan dengan masih berlangsungnya diskusi dan klarifikasi antara pihakpihak terkait mengenai formula harga mulut sumur untuk kilang mini. Pada 23 Juni 2016, Menteri ESDM mengeluarkan keputusan No. 168.K/12/DJM.B/2016 mengenai harga minyak mentah sementara yang akan dijadikan acuan sampai terbitnya aturan permanen mengenai formula harga mulut sumur untuk kilang mini. Hingga akhir Juli 2016, pengiriman minyak mentah untuk TWU masih dalam proses. Di sektor konsumer, PT Mitra Pinasthika Mustika Tbk. (kode saham: MPMX), perusahaan konsumer otomotif terkemuka di Indonesia, terus memperkuat fundamental bisnisnya, meningkatkan efisiensi operasional serta melakukan sejumlah inisiatif strategis untuk meningkatkan nilai kompetitifnya.

Sebagai hasilnya, MPMX berhasil membukukan pertumbuhan pendapatan sebesar $9 \%$ menjadi Rp 8,9 triliun pada Semester I 2016 dibandingkan periode yang sama tahun lalu. MPMX juga berhasil mencetak laba bersih yang diatribusikan kepada entitas induk mencapai Rp 180 miliar di Semester I 2016.Sebagai bagian dari komitmen perusahaan kepada pemegang saham, MPMX telah membagikan dividen kepada pemegang saham sebanyak Rp 75,9 miliar atau sebesar 2,5 kali lebih besar dibandingkan dengan tahun sebelumnya. Nilai dividen ini merupakan $26,6 \%$ dari laba yang dapat diatribusikan kepada pemilik entitas induk.

Praktik perataan laba terkait erat dengan manajemen laba, yaitu praktik manajemen laba dipengaruhi oleh konflik kepentingan antara manajemen (agent) 
A. A. Sagung Nur Andiani dan Ida Bagus Putra Astika. Pengaruh ...

dan pemilik (principal) (Sidartha, 2017). Dalam teori keagenan (agency theory) dinyatakan bahwa praktik manajemen laba yang dilakukan manajemen suatu badan usaha dipengaruhi oleh adanya konflik kepentingan. Agen (manajemen) yang semestinya melaksanakan fungsi pelayanan kepada prinsipal ternyata memiliki tujuan yang berbeda dengan tujuan prinsipal. Tiap-tiap pihak berusaha untuk mencapai atau mempertahankan tingkat kemakmuran yang mereka kehendaki (Astika, 2010). Alasan mengapa peristiwa perataan laba ini perlu diteliti karena timbulnya kerugian bagi pihak - pihak yang berkepentingan terhadap perusahaan karena adanya praktik perataan laba tersebut. Adanya perataan laba mengakibatkan pengungkapan informasi mengenai laba menjadi keliru. Hal tersebut mengakibatkan terjadinya kesalahan didalam pengambilan keputusan oleh pihak eksternal.

Terdapat banyak faktor yang mempengaruhi perataan laba salah satunya yaitu struktur kepemilikan dan ukuran perusahaan. Faktor pertama yang mempengaruhi perataan laba yaitu struktur kepemilikan. Struktur kepemilikan mencerminkan distribusi kekuasaan dan pengaruh diantara para pemegang saham atas kegiatan operasional perusahaan. Struktur kepemilikan memiliki dua bentuk yaitu struktur kepemilikan terkonsentrasi dan menyebar (Wang dan William, 2011). Kepemilikan terkonsentrasi biasanya ditemukan pada Negara yang ekonominya sedang berkembang sedangkan struktur kepemilikan menyebar lebih banyak ditemui di Negara yang memiliki perlindungan yang bagus terhadap pemegang saham terutama pemegang saham minoritas. Secara spesifik kategori struktur kepemilikan meliputi kepemilikan oleh institusi domestik, institusi asing, 
pemerintah, karyawan, dan individual domestik (Dewi dan Sujana, 2014).

Pada penelitian ini struktur kepemilikan akan diproksikan oleh struktur kepemilikan manajerial dan struktur kepemilikan institusional Menurut Carlson dan Bathala (1997) dalam Sari (2014) perbedaan dalam struktur kepemilikan manajerial mempengaruhi prilaku perataan laba. Struktur kepemilikan merupakan bentuk komitmen dari para pemegang saham untuk mendelegasikan pengendalian dengan tingkat tertentu kepada para manajer. Istilah struktur kepemilikan digunakan untuk menunjukkan bahwa variabel-variabel yang penting didalam struktur modal tidak hanya ditentukan oleh jumlah utang dan equity tetapi juga oleh persentase kepemilikan oleh manajer dan institusional.

Struktur kepemilikan akan memiliki motivasi yang berbeda dalam memonitor perusahaan serta manajemen dan dewan direksinya. Struktur kepemilikan dipercaya memiliki kemampuan untuk mempengaruhi jalannya perusahaan yang nantinya dapat mempengaruhi kinerja perusahaan.

Penelitian Giovani (2017) menyatakan bahwa struktur kepemilikan tidak berpengaruh terhadap praktik praktik perataan laba. Hal itu berarti besar kecilnya presentase kepemilikan saham oleh perusahaan tidak memengaruhi kecenderungan untuk melakukan perataan laba. Namun hasil penelitian ini tidak konsisten dengan hasil penelitian penelitian Nazira dan Ariani (2016) yang menghasilkan bahwa struktur kepemilikan berpengaruh pada tindakan perataan laba.

Faktor kedua yang mempengaruhi perataan laba yaitu Ukuran perusahaan Teori Akuntansi positif yang dirumuskan oleh Watts dan Zimmerman (1990) 
A. A. Sagung Nur Andiani dan Ida Bagus Putra Astika. Pengaruh ...

menyatakan tiga hipotesis yaitu the bonus plan hypothesis, the dept/equity hypothesis (debt convenant hypothesis) dan the political cost hypothesis (size hypothesis). Ukuran perusahaan berhubungan dengan the political cost hypothesis (size hypothesis) yang menyatakan semakin besar perusahaan semakin besar pula kemungkinan perusahaan tersebut memilih metode akuntansi yang menurunkan laba untuk menghindari pajak yang tinggi. Secara umum, besarnya suatu perusahaan dinilai dari besarnya asset perusahaan tersebut. Perusahaan yang memiliki total asset yang besar cenderung akan melakukan perataan laba dibandingkan perusahaan yang memiliki ukuran yang lebih kecil, disebabkan karena perusahaan yang memiliki laba yang besar cenderung akan lebih menjadi perhatian publik dan juga akan dikenakan pajak oleh pemerintah lebih tinggi (Dewi dan Sujana, 2014).

Penelitian (Suryani dan Damayanti, 2015) dan (Desnasari, 2013) menemukan bahwa ukuran perusahaan tidak berpengaruh terhadap perataan laba. Dengan tidak adanya pengaruh, berarti besar kecilnya perusahaan tidak akan memengaruhi tingkat perataan laba. Sedangkan pada penelitian (Gayatri dan Wirakusuma, 2013) ukuran perusahaan berpengaruh pada praktik perataan laba.

Alasan penulis memilih perusahaan manufaktur sebagai objek penelitian adalah yang pertama penelitian sebelumnya lebih cenderung menggunakan perusahaan pertambangan, yang kedua perusahaan manufaktur yang terdaftar di BEI terdiri dari berbagai sub sektor industri sehingga dapat mencerminkan reaksi pasar modal secara keseluruhan. Alasan lainnya karena perusahaan manufaktur adalah perusahaan yang memiliki produksi yang berkesinambungan sehingga 
diperlukan pengelolaan modal dan aktiva yang baik sehingga menghasilkan profit yang besar untuk memberikan kembalian investasi yang besar pula sehingga dapat menarik investor untuk menanamkan modalnya.

Pentingnya penelitian ini karena perataan laba merupakan salah satu fenomena yang dilakukan oleh manajemen untuk menjaga citranya dimata publik, sehingga diharapkan hasil penelitian ini mampu menjadi pertimbangan bagi pihak terkait dalam pengambilan keputusan sehubungan dengan investasi yang akan dilakukan.

Kepemilikan manajerial dianggap sebagai salah satu faktor yang berpengaruh terhadap Praktik Perataan laba yang dilakukan manajer. Jika manajer mempunyai kepemilikan pada perusahaan, maka manajer akan bertindak sesuai dengan kepentingan pemegang saham karena manajer juga mempunyai kepentingan di dalamnya. Besar kecilnya jumlah kepemilikan saham manajerial dalam perusahaan dapat mengindikasikan adanya kesamaan (congruence) kepentingan antara manajemen dengan pemegang saham, namun jika kepentingan manajer dan pemilik dapat disejajarkan, manajer tidak akan termotivasi untuk memanipulasi informasi atau melakukan Praktik Perataan laba sehingga kualitas informasi akuntansi dan keinformatifan laba dapat meningkat. Dengan memperbesar kepemilikan manajerial diharapkan dapat mengurangi tindakan praktik perataan laba.

Dapat dikatakan bahwa semakin besar proporsi kepemilikan manajerial dalam suatu perusahaan, maka manajemen berupaya lebih giat untuk memenuhi kepentingan pemegang saham yang juga adalah dirinya sendiri, dengan 
A. A. Sagung Nur Andiani dan Ida Bagus Putra Astika. Pengaruh ...

melakukan perataan laba untuk meningkatkan kepercayaan investor untuk tetap berinvestasi pada perusahaan (Prayudi, 2013) Berdasarkan penjelasan tersebut maka penelitian Hipotesisnya adalah:

$\mathrm{H}_{1}$ : Struktur kepemilikan manajerial berpengaruh positif pada praktik perataan Laba.

Kepemilikan institusional merupakan salah satu cara untuk memonitor kinerja manajer dalam mengelola perusahaan sehingga dengan adanya kepemilikan oleh institusi lain diharapkan bisa mengurangi Praktik Perataan Laba yang dilakukan manajer. Kepemilikan institusional memiliki kemampuan untuk mengendalikan pihak manajemen melalui proses monitoring secara efektif. Tindakan pengawasan tersebut dapat mendorong manajer untuk lebih memfokuskan perhatiannya terhadap kinerja perusahaan, sehingga akan mengurangi perilaku opportunistic atau mementingkan diri sendiri. investor institusional merupakan pihak yang dapat memonitor agen dengan kepemilikannya yang besar, sehingga motivasi manajer untuk mengatur laba menjadi berkurang. Persentase saham tertentu yang dimiliki oleh institusi dapat mempengaruhi proses penyusunan laporan keuangan yang tidak menutup kemungkinan terdapat akrualisasi sesuai kepentingan pihak manajemen.

(Santoso dan Salim, 2012) menyatakan bahwa dalam hubungannya dengan fungsi monitor, investor institusinal diyakini memiliki kemampuan untuk memonitor tindakan manajemen lebih baik dibandingkan investor individual. Pengaruhnya terhadap tindakan perataan laba adalah positif karena investor institusional adalah pemilik sementara (transfer owner) sehingga hanya terfokus pada laba sekarang. Perubahan pada laba sekarang dapat mempengaruhi 
keputusan investor institusional. Jika perubahan tersebut tidak dirasakan menguntungkan oleh investor, maka investor dapat melikuidasi sahamnya. Investor institusional biasanya memiliki saham dalam jumlah yang besar, sehingga jika melikuidasi sahamnya akan mempengaruhi nilai saham secara keseluruhan. Untuk menghindari hal tersebut maka manajer akan cenderung melakukan tindakan perataan laba. Berdasarkan penjelasan tersebut maka hipotesis penelitiannya adalah:

$\mathrm{H}_{2}$ : Struktur kepemilikan institusional berpengaruh positif pada praktik perataan laba.

Ukuran Perusahaan pada penelitian ini diukur melalui total ekuitas yang dimiliki oleh perusahaan. Ukuran perusahaan secara umum dapat diartikan sebagai suatu perbandingan besar atau kecilnya suatu objek. Pengukuran perusahaan bertujuan untuk membedakan secara kuantitatif antara perusahaan besar (large firm), perusahaan sedang (medium firm), dan perusahaan kecil (small firm). Dalam Kaitannya dengan teori sinyal menggambarkan pentingnya informasi yang dikeluarkan oleh perusahaan terhadap keputusan investasi dari investor di pasar modal. Perataan laba dilakukan untuk membuat laba yang dilaporkan lebih stabil karena hal ini akan mempengaruhi keputusan investor untuk menginvestasikan dananya. Semakin besar ukuran perusahaan tersebut maka semakin besar pula manajemen melakukan praktik perataan laba. Hal tersebut didukung oleh penelitian (Dewi dan Sujana, 2014) yang mengatakan bahwa ukuran perusahaan berpengaruh Positif dan signifikan pada praktik perataan laba. Berdasarkan penjelasan tersebut maka hipotesisnya adalah: $\mathrm{H}_{3}$ : Ukuran Perusahaan berpengaruh Positif pada praktik perataan laba. 


\section{METODE PENELITIAN}

Penelitian ini dilakukan pada perusahaan Manufaktur yang terdaftar di Bursa Efek Indonesia (BEI) pada tahun 2013 sampai 2017. Data diperoleh dengan mengakses dan mengunduh data laporan keuangan dari situs resmi Bursa Efek Indonesia (BEI).

Index Eckel untuk menentukan perataan laba dihitung dengan rumus berikut (Eckel, 1981).

Indeks Eckel $=\frac{C V \Delta I}{C V \Delta S}$

Keterangan:

$\Delta \mathrm{I} \quad$ : Perubahan laba bersih setelah pajak dalam satu tahap pelaporan

$\Delta S \quad$ : perubahan penjualan bersih dalam satu periode

$\mathrm{CV} \quad$ : koefisien Variasi yaitu standar deviasi dibagi dengan nilai yang diharapkan.

CV $\Delta \mathrm{I}$ dihitung sebagai berikut:

$$
\mathrm{CV} \Delta \mathrm{I}=\frac{\sqrt{\Sigma(\Delta \mathrm{I}-\Delta \mathrm{x})^{2}}}{\mathrm{n}-1}: \Delta
$$

Keterangan:

$\Delta \mathrm{I} \quad$ : Perubahan laba bersih setelah pajak tahun $\mathrm{n}-1$

$\Delta \mathrm{X} \quad$ : Rata - rata perubahan laba bersih setelah pajak tahun $\mathrm{n}-1$

$\mathrm{n} \quad$ : Banyaknya tahun yang diteliti

CV $\Delta$ S dihitung sebagai berikut:

$$
\mathrm{CV} \Delta \mathrm{S}=\frac{\sqrt{\Sigma(\Delta \mathrm{S}-\Delta \mathrm{x})^{2}}}{\mathrm{n}-1}: \Delta \mathrm{X}
$$

Keterangan:

$\Delta \mathrm{S} \quad$ : Perubahan penjualan bersih tahun $\mathrm{n}-1$

$\Delta \mathrm{X} \quad$ : Rata - rata penjualan bersih antara tahun $\mathrm{n}-1$

$\mathrm{n} \quad$ : Banyaknya tahun yang diteliti

Kepemilikan manajerial adalah proporsi kepemilikan saham yang dimiliki oleh pihak manajemen dan biasanya dinyatakan sebagai persentase saham 
perusahaan yang beredar yang dimiliki oleh orang dalam perusahaan (manajer, komisaris dan direksi) Zaitul dan Muslim (2014). Kepemilikan Manajerial dapat dirumuskan sebagai Berikut:

$\mathrm{KM}=\frac{\text { Jumlah Saham Manajemen }}{\text { Total saham perusahaan }}$

Kepemilikan institusional dapat meningkatkan pengawasan terhadap kinerja manajemen perusahaan. Dengan adanya peningkatan pengawasan terhadap kinerja manajemen diharapkan manajemen akan semakin bekerja dengan lebih baik sehingga meningkatkan nilai perusahaan itu sendiri di masa mendatang (Puspitasari dan Putra, 2018). Kepemilikan Institusional dihitung dengan rumus:

$\mathrm{KI}=\frac{\text { Jumlah Saham Institusi }}{\text { Total Saham Perusahaan }}$

Dalam penelitian ini ukuran perusahaan diukur dari jumlah total asset yang dimiliki oleh perusahaan. Karena total asset mencerminkan besarnya ukuran perusahaan (Arum, 2017). Ukuran untuk menentukan ukuran perusahaan adalah dengan menggunakan log natural dari total asset. Penggunaan natural log (Ln) dalam penelitian ini dimaksudkan untuk mengurangi fluktuasi data yang berlebih. Jika total asset langsung dipakai begitu saja maka nilai variabel akan sangat besar, miliar bahkan triliun. Dengan menggunakan natural log, nilai tersebut disederhanakan, tanpa mengubah proporsi dari nilai asal yang sebenarnya. Secara matematis ukuran perusahaan dapat dirumuskan sebagai berikut:

Ukuran Perusahaan $=$ Ln. Total Asset

Populasi dalam penelitian ini adalah seluruh perusahaan Manufaktur yang terdaftar dalam Bursa Efek Indonesia Tahun 2013 - 2017. Sampel yang digunakan dalam penelitian ini adalah Perusahaan Manufaktur yang terdaftar di 
A. A. Sagung Nur Andiani dan Ida Bagus Putra Astika. Pengaruh ...

Bursa Efek Indonesia selama periode penelitian tahun 2013 - 2017 dan telah memenuhi kriteria.

Pengujian hipotesis dilakukan dengan menggunakan model regresi logistik. Alasan menggunakan regresi logistik adalah karena variabel dependennya merupakan variabel dummy. Regresi logistik dapat digunakan tanpa memenuhi uji normalitas pada variabelnya. Hal ini dikarenakan variabel independennya merupakan campuran antara variabel kontinyu (metric) dan kategorial (non - metric). Dalam hal ini dapat di analisis dengan binary logistic. Berikut ini disajikan model statistik untuk menguji hipotesis:

$\operatorname{Ln} \frac{\mathrm{IS}}{1-\mathrm{IS}}=\alpha+\beta 1 \mathrm{KM}+\beta 2 \mathrm{KI}+\beta 3 \mathrm{UP}+\varepsilon$

Keterangan:

IS : Praktik Perataan Laba (Income Smoothing)

$\alpha \quad$ : Konstan

KM : Kepemilikan Manajerial

KI : Kepemilikan Institusional

UP : Ukuran Perusahaan

$\varepsilon \quad:$ error

$\beta 1, \beta 2, \beta 3 \quad$ : Nilai dari Koefisien Regresi

\section{HASIL DAN PEMBAHASAN}

Berdasarkan pengelohan data SPSS tentang pengujian statistik deskriptif mengenai variabel Struktur kepemilikan, ukuran perusahaan, dan perataan laba maka didapatkan hasil analisis yang disajikan dalam tabel 1. 
Tabel 1.

Statistik Deskriptif

\begin{tabular}{lcrrrr}
\hline & N & \multicolumn{1}{c}{ Minimum } & Maximum & \multicolumn{1}{c}{ Mean } & Std. Deviation \\
\hline Kepemilikan & 125 & 0,000001 & 0,115385 & 0,02662994 & 0,033898761 \\
$\begin{array}{l}\text { Manajerial } \\
\text { Kepemilikan }\end{array}$ & 125 & 0,322156 & 0,960912 & 0,64937462 & 0,156233992 \\
$\begin{array}{l}\text { Institusional } \\
\text { Ukuran Perusahaan }\end{array}$ & 125 & 25,619483 & 31,832124 & 28,30573601 & 1,596387131 \\
Perataan Laba & 125 & 0 & 1 &, 37 &, 484 \\
Valid N (listwise) & 125 & & & & \\
\hline Suld (istar
\end{tabular}

Sumber: Data diolah, 2018

Kepemilikan Manajerial memiliki Nilai minimum sebesar 0,001 Pada PT Astra Auto Part Tbk sedangkan nilai maximum sebesar 0,115 Pada Pyridam Farma Tbk. Dapat diartikan bahwa Kepemilikan Manajerial pada Perusahaan Manufaktur tahun 2013-2017 memiliki kepemilikan manajerial dimana kepemilikan manajerial terbesar yaitu 0,115 dan kepemilikan manajerial terkecil yaitu 0,001. Rata-rata Kepemilikan Manajerial perusahaan manufaktur pada tahun 2013-2017 yang terdaftar di BEI adalah sebesar 0,0266. Dengan nilai standar deviasi sebesar 0,0338 .

Kepemilikan Institusional memiliki nilai minimum sebesar 0,322 pada PT. Lionmesh Prima Tbk sedangkan nilai maximum sebesar 0,960 pada PT. Sekar Laut Tbk. Dapat diartikan bahwa Kepemilikan Institusional pada perusahaan manufaktur yang di tahun 2013-2017 memiliki Kepemilikan Institusional dimana kepemilikan terbesar yaitu 0,960 dan yang terkecil yaitu 0,322. Rata-rata Kepemilikan Institusional perusahaan manufaktur pada tahun 2013-2017 yang terdaftar di BEI adalah sebesar 0,649. Dengan nilai standar deviasi sebesar 0,156.

Ukuran perusahaan memiliki nilai minimum sebesar 25,619 pada PT. Lionmesh Prima Tbk sedangkan nilai maximum sebesar 31,832 pada PT. Gudang garam Tbk. Hal tersebut menunjukkan bahwa perusahaan manufaktur yang 
A. A. Sagung Nur Andiani dan Ida Bagus Putra Astika. Pengaruh ...

terdaftar di Bursa Efek Indonesia tahun 2013-2017 memiliki ukuran perusahaan terbesar yaitu 31,832 dan yang terkecil yaitu 25,619. Rata-rata ukuran perusahaan Manufaktur yang terdaftar di BEI Periode 2013-2017 adalah sebesar 28,305. Dengan Nilai standar deviasi sebesar 1,596.

Perataan Laba memiliki nilai minimum 0 dan nilai maximum 1 . Hal ini menunjukkan variabel perataan laba merupakan variabel dummy dimana angka 0 menunjukkan perusahaan yang tidak melakukan perataan laba, sedangkan angka 1 menunjukkan perusahaan tersebut melakukan perataan laba. Nilai rata-rata perataan laba sebesar 0,38. Dengan niali standar deviasi sebesar 0,488. Berikut adalah hasil yang ditampilkan dalam Tabel 2.

Tabel 2.

Hosmer and Lemeshow Test

\begin{tabular}{llllll}
\hline Step & Chi-square & df & & Sig. & \\
\hline 1 & 8,923 & & 8 & & 0,349 \\
\hline
\end{tabular}

Sumber: Data diolah, 2018

Berdasarkan Tabel 2 Pengujian menunjukkan nilai chi-square sebesar 8,923 dengan signifikansi sebesar 0,349. Berdasarkan Hasil Penelitian tersebut, karena nilai signifikansi lebih besar dari 0,05 maka dapat disimpulkan bahwa model tersebut dapat diterima dikarenakan cocok dengan data observasinya. Hal ini juga menunjukkan bahwa model dikatakan fit dan model ini dapat diterima karena cocok dengan data yang sebenarnya.

Statistik yang digunakan berdasarkan pada fungsi likelihood. Penurunan likelihood (-2LL) menunjukkan model regresi yang lebih baik atau dengan kata lain model yang dihipotesiskan fit dengan data. Pengujian ini dilakukan dengan membandingkan nilai antara -2Log Likelihood (-2LL) pada awal (Block Number $=$ 
0) dengan -2 log Likehood (-2LL) pada akhir (Block Number = 1). Hasil uji ini dapat ditampilkan dalam Tabel 3 sebagai berikut:

Tabel 3.

Perbandingan nilai -2LL Awal dengan -2LL Akhir

-2LL awal (Block Number $=0$ )

164,471

-2LL akhir (Block Number $=1$ )

152,508

Sumber: Data diolah, 2018

Berdasarkan Tabel 3 dapat dilihat bahwa nilai -2log Likehood (-2LL) awal (Block Number $=0$ ) adalah sebesar 164,471 dan setelah dimasukkan variabelvariabel independen maka nilai -2log Likehood (-2LL) akhir (Block Number $=0$ ) mengalami penurunan menjadi 152,508 . Penurunan nilai -2LL ini menunjukkan model regresi yang lebih baik atau dengan kata lain model yang dihipotesiskan fit dengan data. Berikut adalah hasil dari pengujian Nagelkerke's $R$ Square yang disajikan dalam tabel 4.

Tabel 4.

Koefisien Determinasi

\begin{tabular}{lcrr}
\hline Step & -2 Log likelihood & Cox \& Snell R Square & Nagelkerke R Square \\
\hline 1 & $152,508^{\text {a }}$ & 0,091 & 0,125 \\
\hline Sumber: Data diolah, 2018 & & &
\end{tabular}

Berdasarkan Tabel 4 dapat dilihat bahwa nilai Nagelkerke's $R$ Square yang sebesar 0,125 atau sama dengan $12,5 \%$ Angka tersebut berarti variabilitas variabel dependen yang dapat dijelaskan oleh variabel independen dalam penelitian ini adalah sebesar $12,5 \%$, sedangkan $87,5 \%$ dijelaskan oleh variabel - variabel lain yang tidak disebutkan dalam model penelitian ini.

Pengujian Multikolinearitas dalam regresi logistik dapat dilihat dari tabel matriks korelasi. Apabila nilai matriks korelasi lebih kecil dari 0,8 artinya tidak terdapat gejala multikolinearitas yang serius antar variabel tersebut, sedangkan 
A. A. Sagung Nur Andiani dan Ida Bagus Putra Astika. Pengaruh ...

jika nilai matrik korelasinya lebih besar dari 0,8 artinya terjadi gejala multikolinearitas. Berikut hasil uji matrik korelasi yang disajikan dalam tabel 5.

\section{Tabel 5.}

Matrik Korelasi

\begin{tabular}{rlrrrr}
\hline & & Constant & \multicolumn{1}{c}{ X1 } & \multicolumn{1}{c}{ X2 } & \multicolumn{1}{c}{ X3 } \\
\hline Step 1 & Constant & 1,000 & $-0,740$ & $-0,417$ & $-0,977$ \\
& X1 & $-0,740$ & 1,000 & 0,542 & 0,650 \\
& X2 & $-0,417$ & 0,542 & 1,000 & 0,220 \\
& X3 & $-0,977$ & 0,650 & 0,220 & 1,000 \\
\hline
\end{tabular}

Sumber: Data diolah, 2018

Hasil pengujian matrik korelasi menunjukkan bahwa, nilai koefisien korelasi antar variabel yaitu lebih kecil dari 0,8 atau dengan kata lain tidak ada koefisien korelasi antar variabel yang nilainya lebih besar dari 0,8 . Hal ini berarti bahwa model regresi pada penelitian ini tidak mengandung gejala multikolinearitas yang serius antar variabel bebas.

Matrik klasifikasi menunjukkan kekuatan prediksi dari model regresi untuk memprediksi kemungkinan terjadinya perataan laba yang dilakukan oleh perusahaan manufaktur yang terdaftar di BEI Periode 2013-2017. Berikut adalah hasil uji matsik klasifikasi disajikan pada Tabel 5.

Tabel 6. Matrik Klasifikasi

\begin{tabular}{lllrrr}
\hline & & \multicolumn{3}{c}{ Predicted } \\
& & & Perataan Laba & Percentage \\
& Observed & & Tidak & Ya & Correct \\
\hline Step 1 & Perataan Laba & Tidak & 69 & 10 & 87,3 \\
& & Ya & 33 & 13 & 28,3 \\
& \multicolumn{2}{c}{ Overall Percentage } & & & 65,6 \\
\hline Sumber: Data diolah, 2018 & & &
\end{tabular}

Sumber: Data diolah, 2018

Berdasarkan data diatas, kekuatan prediksi dari model regresi untuk memprediksi kemungkinan perusahaan melakukan praktik perataan laba sesuai disajikan dalam tabel 5. Hal tersebut menunjukkan bahwa kekuatan prediksi dari 
model regresi untuk memprediksi kemungkinan bahwa perusahaan tidak melakukan praktik perataan laba yaitu sebesar $87,3 \%$. Nilai tersebut menunjukkan bahwa dari 79 total observasi yang tidak melakukan praktik perataan laba, terdapat 69 total observasi diprediksi tidak melakukan praktik perataan laba sedangkan 10 total observasi diprediksi melakukan praktik perataan laba. Kekuatan prediksi dari kemungkinan bahwa perusahaan melakukan praktik perataan laba yaitu sebesar 28,3\%. Nilai tersebut menunjukkan bahwa dari 46 total observasi yang melakukan praktik perataan laba terdapat 33 total observasi diprediksi tidak melakukan praktik perataan laba, sedangkan 13 total observasi diprediksi melakukan praktik perataan laba.

Analisis yang digunakan dalam penelitian ini adalah analisis regresi logistik, yaitu dengan melihat pengaruh struktur kepemilikan dan ukuran perusahaan pada Praktik Perataan Laba. Model regresi yang terbentuk menghasilkan koefisien regresi dan signifikansi. Koefisien regresi dari tiap variabel yang diuji menunjukkan bentuk hubungan antar variabel. Pengujian hipotesis dilakukan dengan tingkat kesalahan $(\alpha)$. Apabila sig $<\alpha(0,05)$ maka dapat dikatakan variabel bebas berpengaruh signifikan pada variabel terikat. Berikut ini adalah hasil pengujian model regresi yang terbentuk disajikan dalam Tabel 7.

Tabel 7.

Uji Regresi Logistik

\begin{tabular}{|c|c|c|c|c|c|c|}
\hline & & $\mathrm{B}$ & S.E. & Wald & Df & Sig. \\
\hline \multirow[t]{4}{*}{ Step $1^{\mathrm{a}}$} & $\mathrm{X} 1$ & 6,821 & 8,704 & 0,614 & 1 & 0,433 \\
\hline & $\mathrm{X} 2$ & 3,067 & 1,556 & 3,884 & 1 & 0,049 \\
\hline & $\mathrm{X} 3$ & $-0,285$ & 0,173 & 2,734 & 1 & 0,098 \\
\hline & Constant & 5,294 & 5,358 & 0,976 & 1 & 0,323 \\
\hline
\end{tabular}

Sumber: Data diolah, 2018 
A. A. Sagung Nur Andiani dan Ida Bagus Putra Astika. Pengaruh ...

Berdasarkan Tabel 7 diatas, maka model regresi yang terbentuk adalah sebagai berikut:

$$
\operatorname{Ln} \frac{\mathrm{IS}}{1-\mathrm{IS}}=5,294+6,821 \mathrm{X}_{1}+3,067 \mathrm{X}_{2}-0,285 \mathrm{X}_{3}+\varepsilon
$$

Variabel Kepemilikan Manajerial ( $\left.\mathrm{X}_{1}\right)$ Menunjukkan koefisien regresi positif sebesar 6,821 dengan tingkat signifikansi 0,433 yang lebih besar dari $\alpha$ (5\%). Dengan demikian variabel Kepemilikan manajerial tidak berpengaruh pada praktik perataan laba. Maka demikian $\mathrm{H}_{1}$ ditolak serta secara statistik kepemilikan manajerial tidak mampu mempengaruhi praktik perataan laba.

Variabel Kepemilikan Institusional $\left(\mathrm{X}_{2}\right)$ Menunjukkan Koefisien regresi positif 3,067 dengan tingkat signifikansi 0,49 yang lebih kecil dari $\alpha(5 \%)$. Dengan demikian variabel kepemilikan institusional berpengaruh Positif pada praktik perataan laba. Maka demikian $\mathrm{H}_{2}$ diterima serta secara statistik kepemilikan Institusional mampu mempengaruhi Praktik perataan laba.

Variabel Ukuran Perusahaan $\left(\mathrm{X}_{3}\right)$ menunjukkan Koefisien regresi negatif sebesar -0,285 dengan tingkat signifikansi 0,098 yang lebih besar dari $\alpha(5 \%)$. Dengan demikian variabel Ukuran perusahaan tidak berpengaruh pada praktik perataan laba. Maka dengan demikian $\mathrm{H}_{3}$ ditolak serta secara statistik ukuran perusahaan tidak mampu mempengaruhi praktik perataan laba.

Struktur kepemilikan merupakan bentuk komitmen dari para pemegang saham untuk mendelegasikan pengendalian dengan tingkat tertentu kepada para manajer. Kepemilikan manajerial menjadi proksi struktur kepemilikan yaitu merupakan kepemilikan saham oleh kelompok elit perusahaan yang terdiri dari saham yang dimiliki oleh komisaris dan direksi. Melalui regresi logistik telah 
dapat diartikan bahwa struktur kepemilikan manajerial tidak berpengaruh terhadap praktik perataan laba.

Hasil pengujian dengan menggunakan regresi logistik menunjukkan bahwa struktur kepemilikan manajerial memiliki nilai koefisien positif sebesar 6,821 dengan tingkat signifikansi sebesar 0,433 lebih besar dari alpha $(0,05)$. Hasil pengujian tersebut memiliki arti bahwa struktur kepemilikan manajerial tidak berpengaruh pada perataan laba.

Hal tersebut didukung oleh penelitian Zaitul dan Muslim (2014), Sari (2014) yang menyatakan struktur kepemilikan manajerial tidak berpengaruh pada praktik perataan laba. Hal ini menandakan adanya kepemilikan manajerial dalam perusahaan tidak serta merta menunjukkan insentif manajemen untuk melakukan praktik pertaan laba. Alasan ditolaknya hipotesis ini adalah karena rata-rata perusahaan manufaktur yang menjadi sampel dalam penelitian ini dikarenakan memiliki nilai kepemilikan manajerial yang hampir sama. Dengan demikan hasilnya kurang dapat digunakan untuk menunjukkan bahwa kepemilikan manajerial dapat mempengaruhi aktivitas perataan laba oleh manajemen.

Namun hal tersebut mematahkan teori Agency yang menyatakan bahwa struktur kepemilikan manajerial dipercaya memiliki kemampuan untuk mempengaruhi jalannya perusahaan yang nantinya dapat mempengaruhi kinerja perusahaan. Menurut teori Agency, problem dapat dikurangi dengan adanya struktur kepemilikan manajerial. Hasil penelitian ini menunjukkan bahwa struktur kepemilikan manajerial bukan merupakan suatu mekanisme untuk mengurangi konflik antara manajemen dan pemegang saham, meskipun kepemilikan saham 
A. A. Sagung Nur Andiani dan Ida Bagus Putra Astika. Pengaruh ...

manajerial dapat mensejajarkan antara kepentingan pemegang saham dengan manajer.

Hasil pengujian dengan menggunakan regresi logistik menunjukkan bahwa struktur kepemilikan institusional memiliki nilai koefisien positif sebesar 3,067 dengan tingkat signifikansi 0,049 lebih kecil dari alpha $(0,05)$. Hasil pengujian tersebut memiliki arti bahwa struktur kepemilikan istitusional berpengaruh positif pada praktik perataan laba sehingga dapat disimpulkan bahwa hasil penelitian ini diterima.

Penelitian ini sejalan dengan (Pratiwi dan Damayanthi, 2017). yang mengatakan bahwa Kepemilikan institusional berpengaruh positif dan signifikan pada perataan laba. Hal tersebut disebabkan adanya keberadaan investor institusional dianggap mampu menjadi mekanisme monitoring yang efektif dalam setiap keputusan yang diambil oleh manajer. Begitu pula dengan penelitian (Santoso dan Salim, 2012) yang menyatakan struktur kepemilikan berpengaruh positif terhadap praktik perataan laba. Hal tersebut disebabkan kepemilikian institusional akan membuat manajer merasa terikat untuk memenuhi target laba dari investor sehingga mereka akan cenderung terlihat dalam praktik perataan laba.

Dapat disimpulkan bahwa kepemilikan saham oleh pihak institusional dapat diandalkan sebagai badan pegawas yang dapat melakukan monitoring kinerja dari manajemen perusahaan. Dapat dikatakan adanya kepemilikan saham institusional sebagai pemegang saham dapat berdampak atau mengotoritasi manajemen melakukan perataan laba. 
Hasil pengujian dengan menggunakan regresi logistik menunjukkan bahwa Ukuran Perusahaan memiliki nilai keofisien negatif 0,285 dengan tingkat signifikansi 0,098 yang lebih besar dari alpha (5\%). Dengan demikian dapat disimpulkan bahwa variabel Ukuran perusahaan tidak berpengaruh pada praktik perataan laba.

Hal tersebut sejalan dengan penelitian (Suryani dan Damayanti, 2015) yang mengatakan bahwa ukuran perusahaan tidak berpengaruh pada praktik perataan laba. Ukuran perusahaan yang diukur dengan logaritma natural total asset belum mampu mendeteksi adanya pengaruh terhadap praktik perataan laba yang dilakukan oleh perusahaan. Jensen dan Meckling, (1976) menyatakan bahwa semakin besar ukuran perusahaan maka semakin besar pengungkapan yang perlu diungkapkan. Pernyataan tersebut mendasari teori keagenan yang menyatakan bahwa pada perusahaan besar memiliki biaya keagenan yang lebih besar pula. Perusahaan besar akan mengungkapkan informasi yang lebih banyak sebagai upaya mengurangi biaya keagenan tersebut. Maka, ada alasan untuk percaya bahwa perusahaan tidak dapat dijadikan tolak ukur dalam menentukan adanya praktik perataan laba.

\section{SIMPULAN}

Struktur kepemilikan manajerial tidak berpengaruh pada Praktik Perataan Laba pada perusahaan manufaktur yang terdaftar di BEI tahun 2013-2017. Sehingga dapat dikatakan bahwa adanya kepemilikan manajerial didalam struktur kepemilikan tidak serta merta menyebabkan manajemen cenderung melakukan 
A. A. Sagung Nur Andiani dan Ida Bagus Putra Astika. Pengaruh ...

praktik perataan laba.

Struktur kepemilikan institusional berpengaruh positif pada Praktik Perataan Laba pada perusahaan manufaktur yang terdaftar di BEI tahun 2013-2017. Investor institusional dengan kepemilikan saham dalam jumlah besar akan mempunyai dorongan yang cukup kuat untuk mengumpulkan informasi, mengawasi tindakan-tindakan manajemen dan mendorong kinerja yang lebih baik. Dengan adanya kepemilikan institusional akan membuat manajer merasa terikat untuk memenuhi target laba dari investor sehingga mereka akan cenderung terlibat dalam praktik perataan laba.

Ukuran Perusahaan tidak berpengaruh pada praktik perataan laba pada perusahaan manufaktur yang terdaftar di BEI pada tahun 2013-2017. Hal tersebut membuktikan bahwa suatu besar kecilnya perusahaan tidak dapat dijadikan tolak ukur dalam menentukan adanya praktik perataan laba.

Bagi investor diharapkan dapat menginterprestasikan angka laba perusahaan yang tercantum di dalam laporan keuangan. Apabila investor melakukan kesalahan dalam menilai kinerja perusahaan, maka hal ini akan menyebabkan investor mengambil keputusan yang salah dan pada akhirnya dapat menimbulkan kerugian. Investor juga sebaiknya memperhatikan proses bagaimana manajemen memperoleh dan memperlakukan laba tersebut misalnya dengan memperhatikan metode akuntansi yang digunakan dan kebijakan-kebijakan keuangan manajemen yang telah diputuskan.

Bagi perusahaan agar lebih bijaksana dalam menerapkan kebijakan kebijakan akuntansi sehingga tidak dapat merugikan para investor. Bagi peneliti 
selanjutnya diharapkan menggunakan sampel yang lebih luas tidak hanya pada perusahaan manufaktur tetapi seluruh perusahaan yang terdaftar di di bursa efek Indonesia agar hasil yang didapat lebih representative dan peneliti selanjutnya diharapkan menambahkan variabel bebas lainnya yang diprediksi memiliki pengaruh pada praktik perataan laba. Hal tersebut dikarenakan uji koefisien determinasi yang memprediksi presentase variabilitas variabel dependen yang dapat dijelaskan dengan variabel independen sebesar 87,5\% dijelaskan oleh variabel-variabel lain diluar model penelitian seperti: bonus plan, reputasi auditor, kualitas audit dan profitabilitas.

\section{REFERENSI}

Arum, H. N., \& et al. (2017). Profitabilitas, Ukuran Perusahaan, Dan nilai Perusahaan Terhadap Praktik Perataan Laba. Jurnal Riset Akuntansi Kontemporer (JRAK), 9(2), 71-78.

Astika, I. B. P. (2010). Manajemen Laba dan Motif Yang Melandasinya. Ilmiah Akuntansi Dan Bisnis, 5(1).

Desnasari, C. A. (2013). Faktor - Faktor Yang Mempengaruhi Perataan Laba Pada Perusahaan Manufaktur Yang Terdaftar Di Bursa Efek Indonesia. Jurnal Ekonomi STIE PERBANAS.

Eckel, N. (1981). The Smoothing Hypothesis Revisited, 17(1), 28-40.

Gayatri, I. A., \& Wirakusuma, M. G. (2013). Faktor - Faktor yang Mempengaruhi Perataan Laba Perusahaan Manufaktur yang Terdaftar di Bursa Efek Indonesia. E-Journal ,Akuntansi Universitas Udayana, 2(1), 1-20.

Giovani, M. (2017). Pengaruh Struktur Kepemilikan, Tata Kelola Perusahaan, dan Karakteristik Perusahaan Terhadap Manajemen Laba. Jurnal Akuntansi Bisnis, 16(1), 113-129.

Jensen, M. C., \& Meckling, W. H. (1976). Also published in Foundations of Organizational Strategy. Journal of Financial Economics, (4), 305-360. 
Kencana Dewi, Mukhtaruddin, and I. A. P. (2018). Income Smoothing And Market Performance: Empirical Study On Manufacturing Companies Listed In Indonesia Stock Exchange. Investment Management and Financial Innovations, 15(1), 106-110. https://doi.org/10.21511/imfi.15(1).2018.10

Nazira, C. F., \& Ariani, N. E. (2016). Pengaruh Jenis Industri, Kepemilikan Manajerial, Operating Profit Margin Dan Dividend Payout Ratio Terhadap Perataan Laba Pada Perusahaan Yang Terdaftar Di Bursa Efek Indonesia Tahun 2012-2014. Jurnal Ilmiah Mahasiswa Ekonomi Akuntansi, 1(1), 158170.

Pratiwi, N. wayan P. I., \& Damayanthi, I. G. A. E. (2017). Analisis Perataan Laba dan Faktor - faktor yang mempengaruhinya. E-Jurnal Akuntansi Universitas Udayana, 20(1), 496-525.

Prayudi, D., \& Daud, R. (2013). Pengaruh Profitabilitas, Risiko Keuangan, Nilai Perusahaan dan Struktur Kepemilikan Terhadap Prekatik Perataan Laba (Income Smoothing) Pada Perusahaan Manufaktur Yang Terdaftar di Bursa Efek Indonesia 2008-2011. Jemasi, 9(2), 118-134.

Puspitasari, N. K. B., \& Putra, I. M. P. D. (2018). Pengaruh Profitabilitas pada Praktik Perataan Laba dengan Struktur Kepemilikan sebagai Variabel Pemoderasi. E-Jurnal Akuntansi Universitas Udayana, 23(1), 211-239. https://doi.org/https://doi.org/10.24843/EJA.2018.v23.i01.p09

Santoso, E. B., \& Salim, S. N. (2012). Pengaruh Profitabilitas, Financial Leverage, Dividen, Ukuran Perusahaan, Kepemilikan Institusional, Dan Kelompok Usaha Terhadap Perataan Laba Studi Kasus Pada Perusahaan Non-Finansial Yang Terdaftar Di BEI. CBAM-FE UNISSULA, 1(1), 185200.

Sari, L. R. (2014). Pengaruh Ukuran Perusahaan Dan Struktur Kepemilikan Terhadap Praktik Perataan Laba Pada Perusahaan Manufaktur Yang Terdaftar Di Bursa Efek Indonesia, 205(01), 76-77. https://doi.org/10.1192/bjp.205.1.76a

Sidartha, Ayu Ratih Maristanda Erawati, N. M. A. (2017). Pengaruh Ukuran Perusahaan Dan Risiko Keuangan Pada Praktik Perataan Laba Dengan Variabel Pemoderasi Jenis Industri. E-Jurnal Akuntansi Universitas Udayana, 20(2), 1103-1132.

Stuart Michelson, C. W. W. and J. J.-W. (2011). An Analysis of Income Smoothing. International Business \& Economics Research Journal (IBER), 2(1), 71-82. https://doi.org/10.19030/iber.v2i1.3758 
Suryani, Ayu Dewi, \& Damayanti, I. G. A. E. (2015). Pengaruh Ukuran Perusahaan, Debt To Equity Ratio, Profitabilitas dan kepemilikan institusional pada Perataan Laba. E-Jurnal Akuntansi Universitas Udayana, 13(1), 208-223.

Suryani, A. D., \& Damayanti, I. G. A. E. (2015). Pengaruh Ukuran Perusahaan, Growth Opportunity dan Debt To Equity Ratio Terhadap Profitabilitas. EJurnal Akuntansi Universitas Udayana, 4(8), 1-21.

Wang, Z., \& William, T. H. (2011). Accounting Income Smoothing and Stockholder Wealth. Journal of Apllied Business Research. https://doi.org/10.19030/jabr.v10i3.5929

Watts, R. L., \& Zimmerman, J. L. (1990). Positive Accounting Theory: A Ten Year Perspective. University of Rochester, 65, 131. https://doi.org/10.2307/247880

Yustiari, D., \& Sujana, I. ketut. (2014). Pengaruh Ukuran Perusahaan dan Profitabilitas pada Praktik Perataan laba dengan Jenis Industri sebagai variabel Pemoderasi Di Bursa Efek Indonesia. E-Jurnal Akuntansi Universitas Udayana, 8(2), 170-184. https://doi.org/Doi 10.1097/Mnm.0b013e328333bcf5

Zaitul, E., \& Muslim, R. Y. (2014). Pengaruh Struktur Kepemilikan Dan Klasifikasi KAP Terhadap Praktik Perataan Laba (Income Smoothing) Pada Perusahaan yang Terdaftar Di Bursa Efek Indonesia (BEI) Periode 20122014. Jurnal Akuntansi, Fakultas Ekonomi, Universitas Bung Hatta, XIII(1). https://doi.org/10.16066/j.1672-7002.2018.06.005 